\title{
High-Frequency Analysis of Foreign Exchange Interventions: What do we learn?
}

\author{
LUKAS MENKHOFF
}

CESIFO WORKING PAPER NO. 2473

CATEgORy 6: MONETARy POLICY AND InTERnAtional Finance

NOVEMBER 2008

An electronic version of the paper may be downloaded
- from the SSRN website: $\quad$ www.SSRN.com
- from the RePEc website:
- from the CESifo website: 


\title{
High-Frequency Analysis of Foreign Exchange Interventions: What do we learn?
}

\begin{abstract}
The high-frequency analysis of foreign exchange dynamics is helpful in order to better identify the impact of central bank interventions. Evidence robustly shows that interventions do indeed move the exchange rate level in the desired direction. Interventions increase volatility in the short run as they are regarded as information; but they can reduce volatility overall. Ways of transmission may reach beyond the signaling channel and also include the portfolio balance and a damping channel. Finally, interventions are more successful if they obey certain conditions, such as being coordinated among central banks and going with the market and fundamentals.
\end{abstract}

JEL Code: F31, G14, G15, E44.

Keywords: foreign exchange, central bank intervention, high-frequency data, transmission channel.

\author{
Lukas Menkhoff \\ Department of Economics \\ Leibniz University Hannover \\ Königsworther Platz 1 \\ 30167 Hannover \\ Germany \\ menkhoff@gif.uni-hannover.de
}

November 10, 2008

For helpful comments I would like to thank Stefan Reitz, Maik Schmeling and three anonymous referees. I also thank the Center for Economic Studies (Munich) for its generous hospitality, where part of this paper was written. Financial support by the German Research Foundation (Deutsche Forschungsgemeinschaft DFG) is gratefully acknowledged. 


\section{High-frequency analysis of foreign exchange interventions: \\ What do we learn?}

\section{Introduction}

The analysis of central bank interventions in foreign exchange has entered new terrain during the last few years by making use of high-frequency data. Such intraday data is crucial to disentangle the impact of interventions from other determinants of exchange rates. Due to this new approach, we have now gained a much more precise understanding about the effect of interventions, which is also helpful for policy-makers. That is, the analytical "standard raised” (Sarno and Taylor, 2001) in answering some long-standing questions. In addition, new issues have come up, too. This survey addresses both progress made and actual issues.

Central bank interventions belong to the traditional and conventional economic policy tools, although we recognize that this instrument seems to have lost importance among leading industrialized economies since the mid-1990s. ${ }^{1}$ Nevertheless, there are three important reasons to study foreign exchange interventions today: first, even in the main exchange rates there occur interventions until today, in particular from the Japanese, and to an increasing extent by way of so-called oral interventions, i.e. statements of relevant authorities without putting money behind it (Fratzscher, 2006, Park and Song, 2008). Second, interventions are of undiminished importance in many currencies which are not fully flexible. This applies indeed to most currencies in the world, among them crucial ones of our present time, such as the Chinese renminbi, and it applies for example to the currencies within the exchange rate mechanism of the European Monetary System II, such as the Danish krone. Third, the application of the microstructure approach to exchange rates (Lyons, 2001), has been a motivation to analyze extremely detailed and comprehensive data sets which allow new insights into the operations and the impact of central bank interventions in foreign exchange markets to be gained.

The motivation for this paper is primarily derived from the third argument mentioned above, i.e. high-frequency research in foreign exchange. This research "allows precise track-

\footnotetext{
${ }^{1}$ Foreign exchange interventions have experienced controversial and time-varying assessment during the last decades (see Sarno und Taylor, 2001). After a period of almost unequivocal rejection as a means of economic policy at the breakdown of the Bretton Woods system in 1973, the assessment changed several times. Interventions always gained attention because major exchange rates seemed to be misaligned, most obviously the strong US-dollar in early 1985 (Frankel, 1985). At that time the Plaza agreement occurred where the most important central banks successfully coordinated interventions against the US-dollar.
} 
ing of how the market absorbs actual central bank trades" and thus works "like a doctor who has a patient ingest blue dye to determine how it passes through the system" (Evans and Lyons, 2001, p.22). In fact, high-frequency data provide this "blue dye" and we take the use of such intraday data as the key characteristic to define the empirical research being covered by this study. ${ }^{2}$

By contrast, other surveys succeeding Sarno and Taylor (2001) have a different focus. King (2003) distinguishes between policy objectives and tactical objectives of interventions and shows how these different objectives can lead to contrasting recommendations for an optimal intervention policy. Neely (2005) provides a thorough discussion of the empirical literature, distinguishing between time-series and event studies. An emphasis is on methodological problems to control for reverse causality and to potentially consider non-linear dynamic impacts of intervention. A complementary perspective is provided by Vitale (2007), who examines the state of literature from a theoretical microstructure viewpoint. This viewpoint is elaborated in Vitale (2006). Finally, Neely (2008) conducted a questionnaire survey in order to learn about monetary authorities' motivations for interventions, which nicely adds to the other surveys.

The core question of any foreign exchange intervention is of course, whether the central bank is able to influence the market at all. In this respect, high-frequency work has produced some remarkably clear-cut results: first, interventions do move the exchange rate in the desired direction, at least at an intraday horizon. Second, interventions increase volatility in the short run if they are regarded as information, but they may reduce volatility overall. Third, interventions may impact the market not only via a signaling but also via a portfolio balance and a damping channel. Fourth, interventions are more successful if they obey certain conditions, such as being coordinated among central banks.

Our paper is structured in the following way. Section 2 develops a framework from preceding empirical work to motivate and organize the discussion of high-frequency research. Section 3 discusses insights from intervention studies based on quotes and press reports. However, transactions data, which lay the foundation for the main body of research covered in Section 4 are more reliable. The contributions of most recent studies based on order flow data are surveyed in Section 5. Section 6 discusses policy implications and Section 7 concludes.

\footnotetext{
${ }^{2}$ Indeed, Sarno and Taylor (2001) cover due to their paper's genesis in the late 1990s only two of the early high-frequency studies on interventions, i.e. Peiers (1997) and Chang and Taylor (1998).
} 


\section{Preceding empirical work and issues of high-frequency studies}

This section gives a short review of the state of discussion before the high-frequency studies became a major instrument in analyzing exchange rate interventions. In order to provide a systematic overview, we first suggest a simple structure of issues being analyzed in the foreign exchange intervention literature.

At the heart of central bank interventions is of course the objective to influence the exchange rate level or returns when directly focusing on exchange rate changes. This issue is thus put at the start of Figure 1 and is given the issue number 1 . A second issue of interest has been the kind of intervention being conducted, a third debate has discussed potential channels by which interventions may influence exchange rate levels and finally, a fourth issue of research has been about the conditions that help making interventions more successful.

The state of discussion on these four issues in the late 1990s can quickly be summarized as follows: Regarding the price impact of interventions (issue no.1), studies since the 1970s have assessed the price impact of central bank interventions in the major foreign exchange markets with much skepticism. If they concede any effect on the market, then for a very shortrun horizon only, where, unfortunately, convincing empirical evidence was missing at that time. Examples for this position include the so-called Jurgensen Report (see Sarno and Taylor, 2001, for an account). Also, the academic survey studies of Edison (1993) and Almekinders (1995) conclude that there are no very robust relations between interventions and intended changes in exchange rate returns (or volatility)(see also Lewis, 1995). Even Sarno and Taylor (2001) who assess the potential of interventions somewhat more optimistically by referring to the monograph of Dominguez and Frankel (1993) and related work (e.g. Dominguez and Frankel, 1993a), concede the specificity of this study with respect to data and approach.

Moreover, it has been found useful to distinguish between sterilized interventions, where the central bank offsets the intervention impact on the domestic monetary base, and non-sterilized interventions (issue no.2). The latter would clearly have an effect on exchange rates, however, typical interventions nowadays occur in the form of sterilized interventions whose effect is less obvious. The debate on transmission channels of intervention, i.e. issue no.3, has focused on two main channels by which interventions affect the market, i.e. the portfolio balance channel and the signaling channel. The former requires domestic and foreign assets to be imperfect substitutes, an assumption that becomes less relevant in globalizing financial markets. Moreover, the amount of daily interventions is usually a few 100 million US dollars, whereas trading volume may be 100 to 1,000 times as much in the main markets. 
The signaling channel, by contrast, regards interventions as a tool to signal information and intention to market participants and thus does not necessarily depend on the volume of interventions - accordingly, it was seen as the more relevant channel of transmission.

This relates to issue no.4, i.e. the influence from various intervention objectives on the assessment of intervention effects. To give an example, many studies find that "leaning against the wind” is the most prominent ambition but that central banks may differ in their emphasis on possible specifications (see Sarno and Taylor, 2001, p.859). Even if we neglect such differences, how can we measure the success of leaning against the wind as there is an endogeneity problem? Obviously, central banks intervene because they want to change something or at least want to prevent worse developments. Wouldn't it be a success in this sense if interventions could lower the "winds", even if they cannot reverse them? In a regression of interventions on exchange rate changes, however, this may look like a failure because interventions could not change a trend, although they may have weakened the trend. Intervention objectives may cause another important problem in assessing intervention success: the signaling channel naturally assumes that interventions go in the same direction as the stance of monetary policy being credibly signaled by interventions. However, there occur more controversial situations as well (e.g. Kaminsky and Lewis, 1996, Baillie et al., 2000, Vitale, 2003), where interventions may signal just the reverse of monetary policy stance in the sense that interventions are used as instruments because policy does not want to implement otherwise necessary measures, such as interest rate changes (see Goodhart and Hesse, 1993). Then, of course, the effect from interventions is unclear (and does not say anything about the instrument as such).

Overall, there is a clear need of more precise analyses on the effect of foreign exchange interventions and, obviously, high-frequency data are highly welcome in this respect. Their main advantage is allowing for a better identification of intervention impact. Intraday data focus on a narrow time window which contains less noise, i.e. fewer other influences on exchange rates occurring during the day, and which tentatively overcomes the endogeneity problem of interventions. Better measurement is also helpful to identify possible effects from the less powerful sterilized interventions and from the limited volumes used in intervention operations. In summary, analyses based on high-frequency data provide better answers on "old" issues but - in addition - they also address several interesting "new” issues.

Two new issues extend the impact analysis of interventions from the exclusive focus on exchange rate returns (or levels) to volatility and spreads. Of course, the issue of volatility (no.5) is not completely new as the stabilization of volatile markets has always been men- 
tioned as a major motivation for interventions. However, due to the limited impact of interventions, it seems fair to conclude that a relevant measure of volatility in this context should be based on intraday data. This applies analogously to the consideration of spreads, i.e. issue no.6. For a graphical overview about the new issues see Figure 2 which extends Figure 1.

Further new issues include sharpening the analysis of intervention impact by also considering counterfactuals (no.7), the precise identification of interventions not just from press reports but by actual information (no.8), the consideration of a new transmission channel - the damping channel - whose analysis requires high-frequency order flow data (no.9), and finally a systematic analysis of conditions of successful interventions (no.10). ${ }^{3}$

Beyond the scope of this survey, there is still ongoing research on interventions at lower frequencies, where high-frequency information is missing. This includes daily analyses considering trading volume (e.g. Chaboud and LeBaron, 2001, Kim and Sheen, 2006), spillovers between exchange rates (Beine, 2004), less liquid exchange rates (Brandner et al., 2006) and exchange rate modeling (Reitz and Taylor, 2008). The impact of interventions on volatility by a regime switching model is for example based on weekly frequency (Beine et al., 2003, see also Brandner et al., 2006). Interventions’ impact on survey based forecast heterogeneity (Beine et al., 2007) and interventions' impact on real exchange rate behavior (Taylor, 2004) both rely on a monthly frequency. However, we neglect these strands of interesting research in order to keep focus on intraday analyses.

Our further procedure will always refer to the structure of ten issues introduced above but it follows a different order. As the high-frequency intervention literature is largely driven by data availability, we arrange the rest of this survey into three steps that each describe an increasing data quality. ${ }^{4}$ Section 3 discusses studies which use high-frequency data built on quoted prices by dealing banks and news reports about interventions. Section 4 surveys studies which are able to use precise real transaction data. Finally, Section 5 considers studies which analyze order flow data that do not only cover the central bank transactions but also further transactions in the market; moreover, the order flow gives information about the "sign" of transactions, i.e. whether the initiator intends to buy or to sell.

\footnotetext{
${ }^{3}$ There are two specific forms of the signaling channel proposed in the literature, i.e. the noise trader channel (Hung, 1997) and the coordination channel (Sarno and Taylor, 2001, Taylor, 2004). However, I am not aware of an examination of these channels with intraday data.

${ }^{4}$ Alternative organizations would be possible, of course, but I prefer the data perspective as they define the bottleneck for applying various approaches.
} 


\section{Intervention effects estimated on the basis of quotes and press reports}

This section reports on studies making use of quoted exchange rates and press reports about interventions. Three issues have been mainly addressed: first, the identification of intervention impact on exchange rate returns and possibly heterogeneous bank reactions (issue no.1), second, the analysis of exchange rate volatility as a consequence of interventions (no.5), and, third, the analysis of conditions of successful interventions (no.10).

\subsection{Earlier studies}

Probably the first intervention study using high-frequency data was Goodhart and Hesse (1993). They compiled 12 weeks of DEM/USD, JPY/USD and USD/GBP quotes in 1989 (details in Table 1). The quotes were inserted by participating banks in the Reuters FXFX-page. At that time this page was the primary medium for receiving high frequency information in foreign exchange to conduct microstructure analyses. Regarding foreign exchange interventions, Goodhart and Hesse (1993) rely on the information in Reuters headline news, i.e. news provided in real time to the screens of foreign exchange participants, in particular traders. Interestingly, they do not identify a short-term effect of interventions on returns. They do find systematic patterns, however, in the conditions affecting the probability of interventions: central banks tend to intervene in thin markets, when volatility is high and after prior changes in exchange rates.

Peiers (1997) examines the behavior of single banks around interventions. She finds heterogeneity between banks, an information advantage of one bank and increasing (highfrequency) volatility ahead of reported interventions. A third study in this field is Chang and Taylor (1998), who find that volatility is significantly higher in intervention periods and that volatility increases at least 30 minutes before the intervention (see Bonser-Neal and Tanner, 1996, with daily data). Major results hold when Japanese macroeconomic news is considered in an ARCH approach as control variable.

Overall, these early studies indicate that interventions have no clear effect on returns, that banks behave in a heterogeneous way and that interventions occur at volatile times. However, robustness of these results may be questioned because of quite selective time periods, markets and participants covered. Moreover, the identification of interventions is imprecise and causality between interventions and returns (or volatility) also seems to be debatable. The robustness issue is discussed in Section 3.2, whereas the identification and causality concerns require different kinds of data and are thus addressed in Section 4. 


\subsection{Later studies}

The limited data coverage of earlier studies presented in Section 3.1 provided the motivation to expand the scope of analysis. A major contribution in this respect is provided by Dominguez (2003), who analyzes all interventions of the Federal Reserve in the two most important markets, i.e. Deutsche mark/ US dollar and Japanese yen/ US dollar during the period 1987 to August 1995 (missing only two more interventions in the following five years). Fed interventions occurred on 273 days during this nine year period. In the methodological tradition of earlier research, Dominguez (2003) uses an event study approach. She finds robust evidence that interventions influence returns in the intended direction (see also Fatum and Hutchison, 2003, for daily data). The effect of interventions is higher if trading volumes are higher, if interventions occur shortly after important macro announcements and if interventions are coordinated among central banks (see also Humpage, 1999, with daily data). In addition, Dominguez (2003) finds that volatility during the event window is higher on intervention days than non-intervention days of the sample. On intervention days, volatility peaks around interventions but is at the same level after one hour that it was one hour before the intervention. Finally, and in contrast to the finding by Peiers (1997), the increase of volatility at interventions times cannot be linked to any of the most active banks in the market.

In a follow-up paper Dominguez (2006) studies the relation between interventions and volatility in a setup considering the intraday pattern of market activity. Nevertheless, qualitative intraday findings are unchanged and she finds "little evidence that interventions systematically influence volatility beyond the day of the operations” (p.1068). Cai et al. (2001) are the first to use a proxy for order flow, which is highly important in explaining volatility, but it does not eliminate a direct effect from interventions. Finally, Chari (2007) examines 125 banks’ responses to interventions. According to this data, interventions lead to increased volatility and higher spread as found in daily data by Naranjo and Nirmalendran (2000). Focusing on the ten largest banks, reaction patterns in bid-ask spreads to interventions differ markedly between banks and depend on which central banks intervenes.

Overall, these later studies establish - still with limited quote data - that interventions do indeed have short-term effects on returns and that heterogeneity is important (issue no.1), that volatility is higher on intervention days (no.5), that spreads increase after interventions (no.6) and that there are conditions which seem to make interventions more powerful (no.10), i.e. at volatile times, at high trading volumes and in coordination with other central banks. 


\section{Intervention effects estimated on the basis of transaction data}

Despite the progress made by relying on high-frequency exchange rate quotes and news reports about interventions, there is no doubt that intervention effects can be much better measured by relying on transaction data. This data gives exact prices, intervention volume and intervention time, which allows the effect of interventions against competing influences, noise or endogeneity of intervention decisions to be more easily identified.

As this section covers the bulk of the literature, we structure it into six subsections: 4.1 addresses the studies identifying mistakes in press reports about interventions (issue no.7), then there are two sections, 4.2 and 4.3, which focus on two different intervention regimes with respective intervention objectives (no.4), i.e. the Swiss case with occasional interventions in floating exchange rates and the Canadian case with more ambitious stabilization objectives - these cases also address volatility (no.5) and spread (no.6). Recent evidence from other currencies on intervention effects is provided in subsection 4.4. Subsection 4.5 reviews studies providing counterfactual evidence to support the effect of interventions (no.8) and subsection 4.6 gives a short interim summary.

\subsection{Mistakes in intervention press reports}

A first obvious analysis which can be conducted due to the revelation of intervention transactions is a comparison of actual transactions with press reports about interventions. These comparisons consistently find remarkable differences which explain to some extent the often weak intervention effects of earlier studies (see Section 3).

The pioneering study in this line of research is Klein (1993). He analyses US interventions during the years 1985-89 after their precise occurrence had been made public by the Federal Reserve in summer 1991. This period covers 1294 trading days and 232 intervention days, with aggregate values of either dollar purchase or sales of the Federal Reserve for each day. Klein's main finding is that by far most interventions are reported correctly by the New York Times or the Wall Street Journal (larger interventions are reported better) but that there are serious mistakes in press reports in two directions: only $72 \%$ of actual interventions are reported, i.e. $28 \%$ stay unreported, and only $88 \%$ of reported interventions happen at all. Obviously, press reports are a noisy source of actual interventions and accordingly cause limited precision of analyses that have to build on them (as reviewed in Section 3) - this provides an unambiguous and important finding on issue no.7.

This result for the US has later been qualitatively confirmed for Japanese interventions (Frenkel et al., 2004) as well as for Swiss interventions (Fischer, 2006); some details are 
given in Table 2. Although the Swiss experience does not find reported interventions that did not occur, this case study allows the analysis - due to the high-frequency data - of mistakes in reporting precision. Indeed, the quality of Reuters headline news is questionable for the Swiss case as Reuters announcements can be late by hours and not by minutes as typically assumed. In several cases, however, announcements occur slightly before interventions - due to the disclosure practice of the Swiss National Bank. Interestingly, the Japanese case shows that newspaper reports may even miss most actual interventions (in the sample covered by Frenkel et al., 2004), whereas Reuters news seems to be more precise in a longer sample covered by Galati et al. (2005).

\subsection{Intervention in a floating exchange rate: the Swiss case}

The first study analyzing interventions with transaction data is Fischer and Zurlinden (1999, p.663) using a data set that "includes all transactions the SNB [Swiss National Bank] carried out on the Swiss franc/ U.S. dollar market between 1986 and 1994”. The data include 362 interventions on 87 days and 367 further central bank transactions which are not interventions, called customer transactions, on 226 days. All of these interventions are sterilized and coordinated with respective interventions of the Federal Reserve or the Deutsche Bundesbank (3 days with non-sterilized and non-coordinated interventions were excluded from the data set). An interesting aspect of these transactions is the distinction due to the purpose of transaction. As Fischer and Zurlinden (1999, p.665) write: “The SNB informs her counterparties that the transaction is an intervention straight after the deal is concluded”. Thus, the intervention price itself is a regular market price, the same as it is in the case of a customer transaction (which means that the central bank intermediates the order of its customer, the federal government). If interventions have any impact on the market, this has to materialize after the actual transaction.

As Fischer and Zurlinden do not have a time series of either market prices or quotes available, they construct a series by relying on their transaction prices. This implies that the last transaction on each day has to be neglected in the analysis and that intervals are irregularly spaced. In order to account for the last argument, they correct the price changes for the well-known non-linear pattern during the day. Based on this data, they find that interventions have the expected impact on the exchange rate, i.e. buying a currency stabilizes its value, whereas customer transactions do not. This indicates that interventions are not just successful by causing a liquidity effect but that interventions give a signal to the market. This finding is strengthened by the fact that the first intervention of a series has impact, but not so the follow- 
ing ones (and neither have the number of other central banks or the amount of intervention) it seems that market participants correctly anticipate that a first intervention may be followed by more.

The effect of interventions on returns has been further investigated by Payne and Vitale (2003), who add another year to the data (see Table 3 for an overview of intervention studies based on transaction data). Moreover, they use exchange rate quotes (unfortunately no transaction prices) with a 15 minutes frequency to analyze the market. This gives a more detailed picture than the large intraday intervals in the Fischer and Zurlinden (1999) study and yields three insights: interventions have a stronger impact if they are concerted and if they go with the market. Third, returns seem to move in the 15 minutes' interval before the intervention takes place, indicating that there is some anticipation of the later action. In addition, Payne and Vitale (2003) apply the standard SVAR-approach of Habrouck (1991) to separate price impacts of transactions into transitory liquidity effects and longer-lasting information effects. This is an important methodological innovation to the intervention literature as interventions will almost necessarily have an impact due to the taking of liquidity out of the market but this liquidity effect will dry out after a short while, raising the question whether there remains a "permanent” impact. Interestingly, interventions have a significant permanent effect in the interbank market, indicating that interventions are interpreted as informed trades.

Whereas these studies address the impact issue (no.1) with different methods and thus confirm the earlier result of a clear short-term price impact of interventions, the Swiss data have also been used to address a possible impact of interventions on volatility and spread (issues no.5 and 6). The major study in this respect is Pasquariello (2007) who further expands the Swiss data until 1998. He also uses quotes, although at 5 minute intervals. His focus is on exchange rate volatility and liquidity (whereas earlier findings on returns are confirmed). Findings indicate - on a daily aggregate level - that interventions are related with increased and persistent higher volatility and increased spreads, the latter being interpreted as reduced liquidity (picking up the daily analysis of Bossaerts and Hillion, 1991). This is consistent with two interpretations: first, interventions provide new information to the market, which needs to be compounded in prices over time and second, interventions may come at a price to be paid by the private actors, i.e. higher spreads (or reduced liquidity).

Of course, it seems obvious that more evidence beyond the Swiss case is warranted, so we also report findings based on different data sets. 


\subsection{Interventions with ambitious objectives: the Canadian case}

The Bank of Canada was the only other central bank - apart from the Swiss National Bank - to provide exact intervention data, although only to researchers being affiliated to the central bank itself. We give a short review of three studies.

Beattie and Fillion (1999) are the first to analyze the Canadian dollar/ US dollar intervention history between April 1995 and September 1997. This period covers 56 intervention days during which interventions occur at 168 intervals of 10 minute length. Thus, the frequency of interventions is roughly comparable to the Swiss case, whereas the period covered is shorter. There is an interesting feature of the Canadian experience in that the Canadian central bank intended to keep its currency inside a pre-defined band, although without explicitly stating a fixed target zone (see Beattie and Fillion, 1999, for a detailed description). Nevertheless, market participants - according to the account of Beattie and Fillion - correctly anticipated the band. Due to this anticipation interventions can be differentiated into expected, “mechanical” interventions in order to "slow rapid movements of the dollar", thereby reducing volatility (Beattie and Fillion, 1999, p.4), and into unexpected, “discretionary” interventions.

The method applied in this paper differs in two respects from the analysis of the Swiss data: first, Beattie and Fillion (1999) use a time series approach (instead of the event study discussed in Section 4.1), and second, due to the many data that make up the full time series, they are able to control for other determinants that might influence this time series beyond interventions. In particular, this is the first intervention study to control for an intraday seasonal pattern, for daily volatility persistence by way of a GARCH $(1,1)$ model and for several macroeconomic news announcements from Canada and the US.

It follows from the intervention purpose of the Bank of Canada that the study focuses on volatility only, i.e. issue no.5. The effect of intervention on volatility is threefold: first, expected interventions do not matter, unexpected interventions do reduce volatility (although not during a sample extension until January 1998) and the non-intervention band tends to stabilize exchange rate changes (although to an economically small degree only).

The study of D’Souza (2002) takes a somewhat different time period than Beattie and Fillion (1999) in order to cover another regime: the period 1.1996 to 9.1998 matches the above described regime, whereas the central bank did only replenish reserves between 10.1998 and 9.1999. Reserve replenishment serves as a counterfactual to interventions in the spirit of Fischer and Zurlinden (1999). Unfortunately, D’Souza analyzes daily data but has the advantage of breaking down transactions to various participants. His price impact analyses 
show that not all participants have the same impact and that the central bank belongs to the more important ones. However, due to its "leaning against the wind"-policy, it seems problematic to evaluate Bank of Canada interventions by the price impact criterion with daily data. Taking the impact on volatility, D’Souza (2002, p.22) reinforces Beattie and Fillion (1999) in the view that interventions immediately decrease volatility whereas replenishment operations do not, indicating that the non-intervention band has some effect.

More recently, Fatum and King (2005) provide another extension of data and scope. Their period of investigation ends in September 1998; however, it already starts in January 1995 in order to also cover an earlier regime of interventions which was characterized by frequent and purely mechanistic interventions. This regime was superseded by the one described above with less frequent and less mechanistic interventions. Moreover, Fatum and King (2005) take account of so-called “currency co-movement”, i.e. controlling possible intervention effects in the minor Canadian dollar market by considering the overall trend of the US dollar. ${ }^{5}$ The method applied in this study is similar to the event studies of Chang and Taylor (1998) or Payne and Vitale (2003).

Fatum and King (2005) find that intervention changes returns in the intended direction but that the intended effect on exchange rate smoothing and volatility exists only for raw data but not when considering currency co-movement. Moreover, they state that the impact of mechanistic versus discretionary interventions is the same; they interpret this as evidence against the signaling channel and in favor of the portfolio balance channel. It seems interesting to note, however, that the latter may be a bit far reaching, as Beattie and Fillion (1999) provide a different interpretation: they do not find the intended effect of interventions on volatility during the end of their period either and explain this by the inconsistent signals of the central bank as intervention policy and interest rate policy do not fit together.

This (implicit) debate refers again to the more deeply rooted problem; how do we usefully measure the success of central bank interventions, in particular, what is the marginal contribution of interventions? The Canadian experience suggests that the goal of reducing volatility by respective interventions can be met to some extent, but crucially depends on an overall credible policy (no.4). Moreover, it seems difficult for a small country to move the exchange rate against world-wide trends (condition of intervention, issue no.10).

\footnotetext{
${ }^{5}$ Fatum (2008) analyzes the importance of currency co-movement on the same data, but on a daily basis, and finds that this effect weakens the measured impact of intervention.
} 


\subsection{Complementary recent evidence}

The Swiss and Canadian data sets have become outdated to some extent as interventions of these central banks did not occur after 1998. Moreover, we observe major changes in foreign exchange market microstructure (Rime, 2003) which might have an impact on market behavior. Thus there is need of additional and more recent data.

A study covering interventions of the Bank of Japan for the long period from May 1991 to March 2004 is Kim (2007). He addresses the identification problem by breaking down the 24-hour trading day into three time zones, marked by the market opening in Japan, then the Japanese closing (which is slightly ahead of the European opening) and finally the London closing (which occurs during New York afternoon trading and which is hours ahead of the next day's Japanese opening). As Japanese interventions occur mostly around Tokyo lunchtime, this structuring allows one to distinguish immediate effects of intervention on returns and volatility, i.e. during the Japanese market, a first overnight analysis covering the time until London closing and a second overnight time covering the New York afternoon hours.

In accordance with Ito and Yabu (2007), Kim (2007) distinguishes two intervention regimes of the Bank of Japan: until 1995 interventions occurred more frequently but with lesser amounts, i.e. 50 billion yen per day compared to 328 billion yen in the second period. During the first regime, interventions have unwanted short-term effects (during Japanese trading) in that they impact returns in the "wrong" direction and increase volatility. These effects reverse overnight. During the second regime, interventions impact returns immediately and reduce volatility overnight.

The Danish central bank has also recently provided intervention information. Fatum and Pedersen (2007) analyze Danish interventions in the Danish krone/ euro exchange rate for the three-year period January 2002 to December 2004. Market rates are end of 5-minute interval exchange rates, purchased from Olson and Associates. The method is similar to Beattie and Fillion (1999) in that this study applies a time series analysis controlling for intraday pattern, volatility levels and macroeconomic news announcements.

This research provides new insights in three respects: first, it confirms for a recent period that interventions move exchange rates in the intended direction. Second, it applies an endogenous structural break test and shows that the two sub-periods are different. The later, longer sub-period provides more favorable results for intervention policy which is explained by Fatum and Pedersen (2007) by consistency with interest rate policy. Third, as interventions occur bilaterally with single banks and are unannounced, they may need up to 30 minutes to fully impact the market. However, the Danish case cannot easily be transferred to other coun- 
tries, as the Danish krone is part of the European Monetary System encompassing EU members which have not joined the monetary union (yet).

Due to the coverage of currencies and circumstances being still rather limited, it also seems useful to mention studies which address experience from emerging markets, even though the data frequency is not intraday. ${ }^{6}$ Disyatat and Galati (2007) conclude that this literature shows a very high degree of sample dependency, where an intervention effect on the exchange rate level is less clear than the tendency that interventions reduce volatility.

\subsection{Counterfactual evidence to intervention effects on returns}

From a methodological point of view, there may always remain some skepticism about the identification of intervention effects because of two competing influences. First, it seems difficult to fully control for other price relevant determinants and second, intervention times seem to be particular times, thus creating the problem of endogeneity. Therefore it is very useful to review counterfactual evidence (issue no.8), i.e. transactions that are as similar as possible to true interventions but which in effect are not. Three approaches have been developed in the recent literature.

First, there is evidence from the Swiss National Bank as this central bank does not only proceed interventions but also acts as agent for customer transactions of the government and both kinds of transaction data are available in comparable form. As reported in subsection 4.2, Fischer and Zurlinden (1999) show that only interventions impact the subsequent exchange rate whereas customer transactions do not. In a similar vein, D’Souza (2002) shows for Canada that more technical replenishment of reserves has - unlike interventions - no effect on volatility. Obviously, interventions are regarded as informative about future prices, consistent with the signaling channel.

Another approach is chosen by Payne and Vitale (2003), again with the Swiss data. They work with higher frequency data than Fischer and Zurlinden (1999) and have information about order flow in the whole market, which enables them to calculate price impacts. They apply the Hasbrouck (1991) SVAR approach and do not only show that interventions have price impact (see above) but also show that the price impact of interventions is several times larger than the average price impact in the interbank market under review. Thus, central

\footnotetext{
${ }^{6}$ Emerging countries are of interest as interventions occur there more commonly nowadays than in industrialized countries. Moreover, one may expect that interventions are more powerful due to market conditions (see Disyatat and Galati, 2007). In particular, limited market volumes support the relevance of a portfolio balance channel, less credibility (e.g. due to shorter history) of authorities may weaken the signaling channel, whereas the typically greater state influence in financial markets will strengthen the position of an intervening central bank.
} 
banks are obviously regarded as very well informed market participants (see also D’Souza, 2002).

In a third approach, Dominguez and Panthaki (2007) analyze the effect of so-called unrequited interventions, i.e. reported interventions which did not occur in reality. If market participants assume informed trading by central banks, one would expect that even such requited interventions move the market to some degree (as oral interventions do, see Fratzscher, 2006). This would also support the signaling channel but discourage the portfolio balance channel because a portfolio shift does not occur. In fact, this study finds that requited interventions have similar impact as real interventions; again, this supports the notion that central bank interventions are important.

Overall, these different ways of revealing the effect of interventions by counterfactual evidence (issue no.8) contribute to strengthening the view that foreign exchange interventions can be a useful policy tool. At the same time, these findings heighten the stakes against the conduct of secret interventions.

\subsection{Interim summary}

The use of transaction data has in several ways improved our understanding about the working of interventions. The unambiguous result that interventions do indeed impact exchange rate return during the intraday horizon is the most important. The following ingredients have been helpful in confirming this result: first, the use of transaction data has improved precision about the fact and timing of interventions (issue no.7). Second, evidence beyond the G3 countries and the use of various methods have increased confidence in the generality of impact findings (no.1). ${ }^{7}$ A major step in this respect has been - third - the evidence from counterfactuals (no.8).

Then, coverage has been increased by including impact assessment of interventions on (high-frequency) volatility and spreads (no.5, 6). Whereas the majority of findings indicate that interventions go hand in hand with - and possibly lead to - higher volatility and spread, the Canadian experience (and also related evidence from emerging markets) suggests that intervention may also be able to reduce volatility, if this is a policy objective (no.4). Finally and similar to findings in Section 3, the impact of interventions is higher if interventions are concerted among central banks (no.10). Moreover, impact is higher if intervention goes with

\footnotetext{
${ }^{7}$ The additional country evidence - beyond the United States, Japan and Germany - includes Switzerland, Canada and Denmark, the methods include event studies and time-series approaches and interventions' impact is measured by direct price changes as well as by permanent price changes (in the sense of Hasbrouck, 1991).
} 
the market and if it goes with fundamentals, whereas market impact is reduced if world-wide market trends are taken into account.

\section{Intervention effects estimated on the basis of order flow data}

All the studies considered so far analyze the isolated impact of interventions on prices, here exchange rates. If one interprets interventions as an order flow of the central bank, the question arises, in which way this order flow may be different from other flows occurring during the same period and whether it may impact these other flows. Unfortunately, there is hardly any data available in this field. ${ }^{8}$

The conceptual idea motivating the analysis of order flow data is that it may represent information. Lyons (2001) argues that in markets with potentially heterogeneous and spread information, such as foreign exchange, the trading process is a means to incorporate information into prices. The information is approximated by the sign (and potentially the size) of transactions, i.e. order flow. However, there are also liquidity and hedging motivations for transactions, which raises the question whether an observed order flow does indeed represent information. It is thus a consequential procedure to analyze the impact of order flow generated by the central bank, i.e. interventions.

The first work bringing order flow analysis and interventions together is Evans and Lyons (2005). Their aim is to assess the potential of secret intervention by carefully analyzing the price impact of ordinary order flow. Based on hourly data of Deutsche mark/ US dollar rates over four months in 1996 - the same data base as in their seminal paper (Evans and Lyons, 2002) - they estimate the immediate price impact of a 1 billion USD order flow to be 0.44 percent, of which 83 percent persists permanently. This suggests that interventions of respective size would be able to change market equilibrium by way of a portfolio balance effect if secret interventions had the same market impact as interbank order flow, which is assumed in the empirical estimation here. Unfortunately, this study does not directly observe interventions so that conclusions are indicative only.

A step forward is thus the analysis of Scalia (2008), who can include information about interventions in the market for Czech koruna versus euro (CZK/EUR). The market data come from the Reuters 3000 electronic trading system and cover an estimated 35\% share of all order flow in this exchange rate. Even though Scalia (2008) does not have precise intervention data available, he develops reasonable arguments about the existence of interventions on a

\footnotetext{
${ }^{8}$ Vitale (2006, p.21) reports that the Federal Reserve during its last large intervention in 2000 split orders between the electronic brokerage system EBS and direct trading with several banks.
} 
daily basis and their distribution during the day, which can be linked to hourly order flow data. Moreover, he can observe three intervention regimes which are distinguished by the degree to which the market knows about interventions. Better knowledge increases the impact of order flow, indicating that interventions provide information and support the signaling channel. The estimated price impact per 10 million USD order flow starts with 6.6 basis points for totally secret interventions increases to 9.3 basis points for partially expected interventions and almost doubles to 12.2 basis points for expected interventions.

Girardin and Lyons (2007) cover daily Japanese yen/ US dollar rates, interventions and customer order flow of Citibank, representing about 10 percent of the worldwide market. I give a short report of findings because of the pioneering character of this study (despite its daily frequency). It is reassuring that interventions significantly impact exchange rate returns even when controlled for other order flow; there is no robust impact on volatility. A real inspiration for our survey, however, is the question whether interventions impact the order flow of other participants.

The damping channel (issue no.9) hypothesizes that credible interventions dominate the information environment in the market and thus reduce or even eliminate the price impact of private order flow. The coordination channel states that interventions initiate a change in private order flow into the direction set by the central bank. Neither effect, damping or coordination of private order flow, is significantly revealed in the Girardin and Lyons (2007) analysis, but they are conceptually introduced and seem possible in principle. One possible reason why they are not revealed is the daily frequency.

There is so far one study covering total order flow in an interbank market, including that of the central bank (Melvin et al., 2008). The Russian market MICEX had at the time of study - in 2002 - newly introduced a technology similar to the Reuters electronic trading. Even though the country wide "unified trading session” (UTS) is not the single trading platform, as there coexist several regional bourses as well as some direct bilateral trade between banks, the important country-wide exchange rate fixing takes place there. The fixing is relevant for foreign exchange operations of many commercial customers. Moreover, the central bank intervenes in this market to ensure an exchange rate, Russian rouble versus US dollar, which is accepted by authorities. Reuters headline news as well as the order book data indicate that the central bank does not intervene every day, although often. The data period in this study from March 2002 covers 5 days with interventions and 9 days without interventions. This allows the comparison of intervention and non-intervention periods. 
Interventions are conducted by putting two very large limit orders into the market: a cheaper bid and a more expensive ask offer of the dollar create an exchange rate band which, indeed, limits movements of the exchange rate during the sample. Due to voluminous foreign exchange reserves of the Russian central bank allowing for huge intervention orders in relation to normal transactions and due to the overall high importance of the state in the Russian economy, the band seems to be credible.

Based on a relatively short but deep data base, there are the following results: first, exchange rate returns are affected by interventions in the sense that the band set by the central bank holds. Second, the relation between interventions and volatility is complex: seen from the intraday perspective, volatility is higher directly after interventions, indicating that information is flowing into the market. Seen from the daily perspective, volatility is lower during intervention days, indicating that the band seems to dampen volatility, possibly similar to the Canadian experience.

Third, another unique feature of this study of the Russian market is the analysis of informed and uninformed participants in the market who react differently to interventions: the uninformed "accept" the band set by the central bank, whereas the "informed" tend to trade against the band. The latter do not seem to be irrational, as Reuters headline news indicate that fundamentals justify the informed behavior, i.e. expecting a depreciation of the rouble at that time.

There are two more interesting effects of interventions: they increase trading volume and reduce the spread, indicating that liquidity is abundant. This smaller spread in combination with more liquidity brings benefits to the less informed participants in the market.

In summary, it seems that the Russian central bank realizes the gains of a kind of target zone by stabilizing exchange rate volatility and also by reducing trading costs. It thus repeats the success found for the Canadian central bank and avoids the increased costs documented for the Swiss case (Pasquariello, 2007). Of course the informed market participants may realize intermediate profits from the central bank’s "leaning against the wind” strategy.

\section{Implications for intervention policy}

Exchange rate interventions are not only a textbook tool of policy-making in open economies but they also seem to work to some extent, as demonstrated in this survey. In contrast to this prominence there is the fact that major central banks have stopped intervening during the last decade. 
An obvious explanation for this contrast is the rapid growth in transaction volume on foreign exchange markets, roughly by a factor of four over the last 15 years. Regular surveys conducted by the Bank for International Settlements (2007) show that daily transaction volumes in the six main exchange rates are above 100 billion US dollar per day. The relative shift in weight towards "other financial institutions", i.e. fund managers of various kinds, including large currency hedge funds or currency overlay operations is possibly even more relevant than the volume growth and its sheer size (Gehrig and Menkhoff, 2005). Fund managers are - unlike typical bank trading - willing to keep high open positions and thus to potentially speculate against a central bank. Thus the "market power" of major central bank interventions - reflecting mainly a potential portfolio balance channel - has been dramatically weakened. This argument does not apply to the same extent to the situation of smaller markets and in particular to many emerging economies. Their currencies are characterized by smaller transaction volume and at the same time central banks tend to command large currency reserves. Finally, emerging markets can often be steered via capital controls.

This discussion provides some explanation as to why major central banks in particular stopped interventions. In addition, high-frequency research has contributed to the improvement of our understanding of possible success conditions for interventions. The finding that interventions cannot succeed if they do not fit into overall economic policy, in particular monetary policy is intuitely plausible. Moreover, exchange rates move more when interventions go with the market - which is, however, not the normal intervention situation. Finally, the impact of interventions increases if they are coordinated among various central banks, a condition that cannot be taken as fulfilled in a world with diverging national interests.

In summary, neither market developments nor findings of recent research provide the stimulus to make more use of interventions in the main foreign exchange markets - or to express it more positively: interventions can impact the market but only under certain conditions. These conditions are more easily met in minor or emerging markets.

\section{Conclusions}

Recent empirical high-frequency research on central bank interventions in foreign exchange permits answers to longstanding open questions. This may influence the decisions of policy makers as to whether and how to conduct interventions.

Possibly the most controversial question was whether interventions would really affect exchange rate returns or whether the relatively small intervention amounts might get lost in the overwhelming flood of trading volumes. The use of high-frequency data (and transaction 
data) has made it clear that interventions do indeed affect returns in the short-run. Admittedly, a very short-term impact can be due to liquidity effects only. From this perspective, it seems particularly important that counterfactuals have been investigated, such as the finding that interventions move returns but other central bank transactions do not (Fischer and Zurlinden, 1999).

Regarding an intervention impact on volatility, a first important insight is to realize the high degree of endogeneity. Interventions occur at volatile times so it is not enough to compare volatility at intervention with non-intervention days but to observe the change in volatility after interventions. In this respect studies for the major markets find that interventions increase volatility in the short-term, but not beyond the day. Obviously, the fact of interventions is seen as information (thus the first intervention in a sequence sometimes matters most). Unrelated to this finding, credible non-intervention bands (see Canada) or a kind of short-term exchange rate target zones (see Russia) may be able to reduce volatility.

Recent high-frequency research has also shed new light on the importance of transmission channels. Whereas the signaling channel seemed to be the only plausible one considering the relative size of interventions to total trading volume, the focus on order flow may change perception. Accordingly, it is not volume that matters but direction, so that decisive interventions - which go into one direction - may even force markets by "brute force". Moreover, there is some first evidence that interventions may reduce the price impact from private trades via the so-called damping channel. Finally, research has sharpened the understanding of success conditions for interventions (see Section 6).

In summary, knowledge about interventions has much improved. Even if central banks may not feel like operating in a laboratory, they are well informed about important effects of their decisions and also about the necessary requirements to be successful. Nevertheless, several issues require further investigation, among them a better coverage of intervention effects on spreads (in order to learn more about possible intervention costs), a more systematic understanding of intervention effects in emerging markets (where interventions are presently mainly exercised) and a deeper look into the functioning of intervention channels by the application of order flow data (which allow for the most precise measurement). 


\section{References}

Almekinders, Geert J. (1995), Foreign exchange intervention: Theory and evidence, Cheltenham: Edward Elgar.

Baillie, Richard T., Owen F. Humpage and W. Osterberg (2000), Intervention from an information perspective, Journal of International Financial Markets, Institutions and Money, 10, 407-421.

Bank for International Settlements (2007), Triennial central bank survey - Foreign exchange and derivatives market activity in 2007, Basel.

Beattie, Neil and Jean-Francois Fillion (1999), An intraday analysis of the effectiveness of foreign exchange intervention, Bank of Canada Working Paper 1999-4.

Beine, Michel (2004), Conditional covariances and direct central bank interventions in the foreign exchange markets, Journal of Banking and Finance, 28, 1385-1411.

Beine, Michel, Agnès Bènassy-Quéré and Ronald MacDonald (2007), The impact of central bank intervention on exchange-rate forecast heterogeneity, Journal of Japanese and International Economies, 21, 38-63.

Beine, Michel, Sébastian Laurent and Christelle Lecourt (2003), Official central bank interventions and exchange rate volatility: Evidence from a regime-switching analysis, European Economic Review, 47, 891-911.

Bonser-Neil, Catherine and Glenn Tanner (1996), Central bank intervention and the volatility of foreign exchange rates: Evidence from the options market, Journal of International Money and Finance, 15, 853-878.

Bossaerts, Peter and Pierre Hillion (1991), Market microstructure effects of government intervention in the foreign exchange market, Review of Financial Studies, 4, 513-541.

Brandner, Peter, Harald Grech and Helmut Stix (2006), The effectiveness of central bank intervention in the EMS: The post 1993 experience, Journal of International Money and Finance, 25, 580-597.

Cai, Jun, Yan-Leung Cheung, Raymond S.K. Lee and Michael Melvin (2001), 'Once-in-ageneration’ yen volatility in 1998: Fundamentals, intervention, and order flow, Journal of International Money and Finance, 20, 327-347.

Chaboud, Alain and Blake LeBaron (2001), Foreign-exchange trading volume and Federal Reserve intervention, Journal of Futures Markets, 21, 851-860. 
Chang, Yuachen and Stephen J. Taylor (1998), Intraday effects of foreign exchange intervention by the Bank of Japan, Journal of International Money and Finance, 17, 191210.

Chari, Anusha (2007), Heterogeneous market-making in foreign exchange markets: Evidence from individual bank responses to central bank intervention, Journal of Money, Credit and Banking, 39, 1134-1161.

Disyatat, Piti and Gabriele Galati (2007), The effectiveness of foreign exchange intervention in emerging market countries: Evidence from the Czech koruna, Journal of International Money and Finance, 26, 383-402.

Dominguez, Kathryn M.E. (2003), The market microstructure of central bank intervention, Journal of International Economics, 59, 25-45.

Dominguez, Kathryn M.E. (2006), When do central bank interventions influence intra-daily and longer-term exchange rate movements?, Journal of International Money and Finance, 25, 1051-1071.

Dominguez, Kathryn M.E. and Jeffrey A. Frankel (1993), Does foreign exchange intervention work? Institute for International Economics, Washington, D.C.

Dominguez, Kathryn M.E. and Jeffrey A. Frankel (1993a), Does foreign exchange intervention matter? The portfolio effect, American Economic Review, 83, 1356-1369.

Dominguez, Kathryn M.E. and Freyan Panthaki (2007), The influence of actual and unrequited interventions, International Journal of Finance and Economics, 12, 171200.

D’Souza, Chris (2002), A market microstructure analysis of foreign exchange intervention in Canada, Bank of Canada Working Paper 2002-16.

Edison, Hali (1993), The effectiveness of central bank intervention: A survey of post-1982 literature, Essays in International Finance, Princeton University.

Evans, Martin D.D. and Richard K. Lyons (2002), Order flow and exchange rate dynamics, Journal of Political Economy, 110, 170-180.

Evans, Martin D.D. and Richard K. Lyons (2005), Are different-currency assets imperfect substitutes?, in: De Grauwe (ed.), Exchange rate economics: Where do we stand?, Cambridge: MIT Press, 1-38.

Fatum, Rasmus (2008), Daily effects of foreign exchange intervention: Evidence from official Bank of Canada data, Journal of International Money and Finance, 27, 438-454.

Fatum, Rasmus and Michael M. Hutchison (2003), Is sterilized foreign exchange intervention effective after all? An event study approach, Economic Journal, 113, 390-411. 
Fatum, Rasmus and Michael R. King (2005), Rules versus discretion in foreign exchange intervention: Evidence from official Bank of Canada high-frequency data, Working Paper, University of Alberta.

Fatum, Rasmus and Jesper Pedersen (2007), Real-time effects of central bank interventions in the euro market, SCCIE Working Paper 07-07.

Fischer, Andreas M. (2006), On the inadequacy of newswire reports for empirical research on foreign exchange interventions, Journal of International Money and Finance, 25, 1226-1240.

Fischer, Andreas M. and Mathias Zurlinden (1999), Exchange rate effects of central bank interventions: An analysis of transaction prices, Economic Journal, 109, 662-676.

Frankel, Jeffrey A. (1985), The dazzling dollar, Brookings Papers on Economic Activity, No.1, 199-217.

Fratzscher, Marcel (2006) On the long-run effectiveness of exchange rate communication and interventions, Journal of International Money and Finance, 25, 146-167.

Frenkel, Michael, Christian Pierdzioch and Georg Stadtmann (2004), The accuracy of press reports regarding the foreign exchange interventions of the Bank of Japan, Journal of International Financial Markets, Institutions and Money, 14, 25-36.

Galati, Gabriele, William Melick and Marian Micu (2005), Foreign exchange market intervention and expectations: The yen/dollar exchange rate, Journal of International Money and Finance, 24, 982-1011.

Gehrig, Thomas and Lukas Menkhoff (2005), The rise of fund managers in foreign exchange: will fundamentals ultimately dominate?, World Economy, 28, 519-540.

Girardin, Eric and Richard K. Lyons (2007), Does intervention alter private behavior?, Working Paper, GREQUAM Aix-Marseille.

Goodhart, Charles A.E. and Thomas Hesse (1993), Central bank forex intervention assessed in continuous time, Journal of International Money and Finance, 12, 368-389.

Hasbrouck, Joel (1991), Measuring the information content of stock trades, Journal of Finance, 46, 179-207.

Humpage, Owen F. (1999), U.S. intervention: assessing the probability of success, Journal of Money, Credit and Banking, 31, 731-747.

Hung, Juann H. (1997), Intervention strategies and exchange rate volatility: a noise trading perspective, Journal of International Money and Finance, 16, 779-793. 
Ito, Takatoshi and Tomoyoshi Yabu (2007), What promotes Japan to intervene in the forex market? A new approach to a reaction function, Journal of International Money and Finance, 26, 193-212.

Kaminsky, Graciela and Karen Lewis (1996), Does foreign exchange intervention signal future monetary policy? Journal of Monetary Economics, 37, 285-312.

Kim, Suk-Joong (2007), Intraday evidence of efficacy of 1991-2004 Yen interventions by the Bank of Japan, Journal of International Financial Markets, Institutions and Money, 17, 341-360.

Kim, Suk-Joong and Jeffrey Sheen (2006), Interventions in the Yen-dollar spot market: A story of price, volatility and volume, Journal of Banking and Finance, 30, 31913214.

King, Michael R. (2003), Effective foreign exchange intervention: Matching strategies with objectives, International Finance, 6, 249-271.

Klein, Michael W. (1993), The accuracy of reports of foreign exchange intervention, Journal of International Money and Finance, 12, 644-653.

Lewis, Karen (1995), Occasional intervention to target rates, American Economic Review, 85, 691-715.

Lyons, Richard K. (2001), The microstructure approach to exchange rates, Cambridge et al.: MIT Press.

Melvin, Michael, Lukas Menkhoff and Maik Schmeling (2008), Automating exchange rate target zones: Intervention via an electronic limit order book, CESifo Working Paper 2221.

Naranjo, Andy and M. Nimalendran (2000), Government intervention and adverse selection costs in foreign exchange markets, Review of Financial Studies, 13, 453-477.

Neely, Christoper J. (2005), An analysis of recent studies of the effect of foreign exchange intervention, Federal Reserve Bank of St. Louis Review, 87, 685-717.

Neely, Christopher J. (2008), Central bank authorities’ beliefs about foreign exchange intervention, Journal of International Money and Finance, 27, 1-25.

Park, Haesik and Chi-Young Song (2008), Japanese vocal intervention and the yen/dollar exchange rate, Japan and the World Economy, 20, 61-81.

Pasquariello, Paolo (2007), Informative trading or just costly noise? An analysis of central bank interventions, Journal of Financial Markets, 10, 107-143. 
Payne, Richard and Paolo Vitale (2003), A transaction level study of the effects of central bank intervention of exchange rates, Journal of International Economics, 61, 331352.

Peiers, Bettina (1997), Informed traders, intervention and price leadership: A deeper view of the microstructure of the foreign exchange market, Journal of Finance, 52, 15891614.

Reitz, Stefan and Mark P. Taylor (2008), The coordination channel of foreign exchange intervention: A nonlinear microstructural analysis, European Economic Review, 52, 5576.

Rime, Dagfinn (2003), New electronic trading systems in foreign exchange markets, in: Derek C. Jones (ed.), New economy handbook, Academic Press, 469-504.

Sarno, Lucio and Mark P. Taylor (2001), Official intervention in the foreign exchange markets: Is it effective and, if so, how does it work?, Journal of Economic Literature, 34, 839-868.

Scalia, Antonio (2008), Is foreign exchange intervention effective? Some micro-analytical evidence from the Czech Republic, Journal of International Money and Finance, 27, 529-546.

Taylor, Mark P. (2004), Is official exchange rate intervention effective?, Economica, 71, 1-11.

Vitale, Paolo (2003), Foreign exchange intervention: How to signal policy objectives and stabilize the economy, Journal of Monetary Economics, 50, 841-870.

Vitale, Paolo (2006), A market microstructure analysis of foreign exchange intervention, ECB Working Paper No.629.

Vitale, Paolo (2007), An assessment of some open issues in the analysis of foreign exchange intervention, International Journal of Finance and Economics, 12, 155-170. 
Figure 1.The main issues of earlier intervention studies

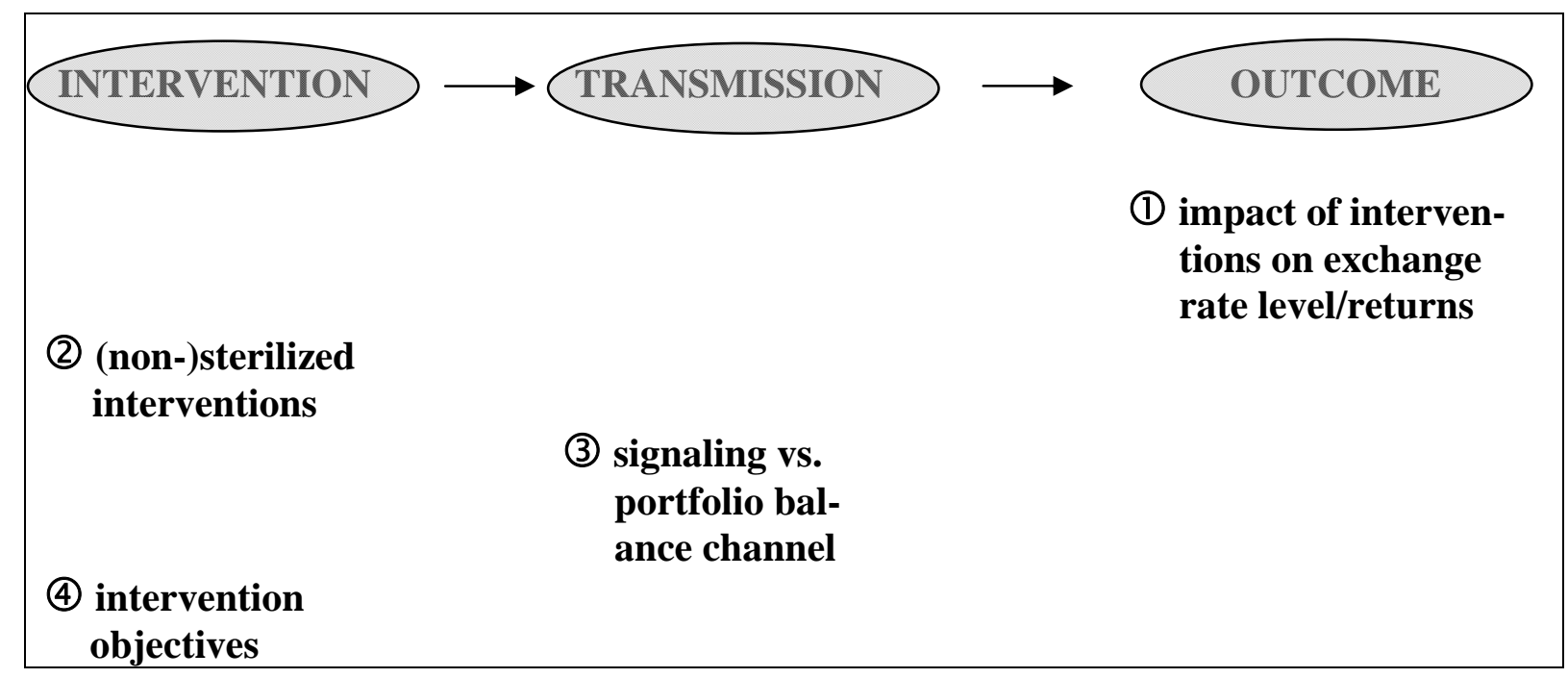

Figure 2. The main issues of high-frequency intervention studies

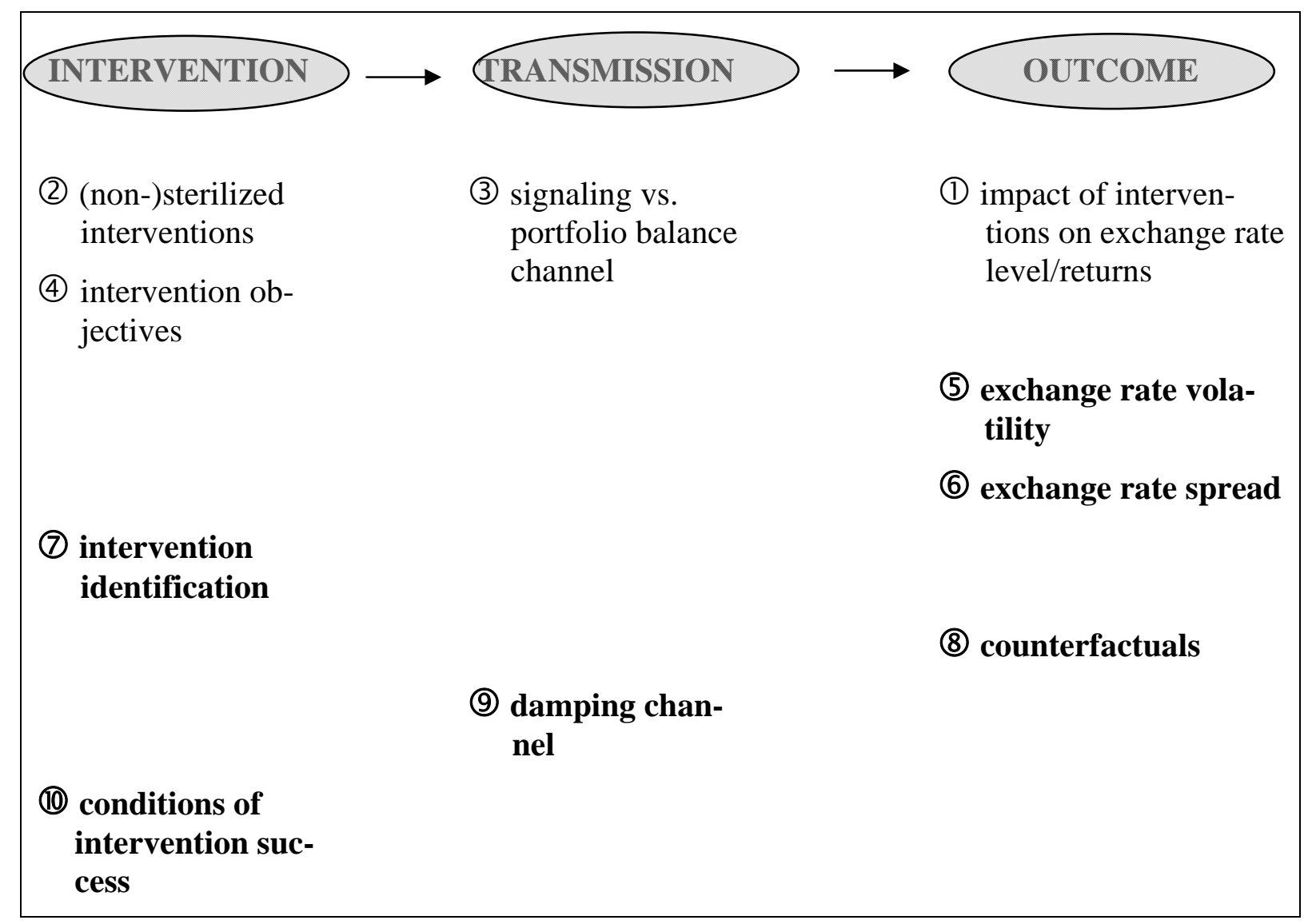


Table 1. Intervention studies based on quotes and press reports

\begin{tabular}{|c|c|c|c|c|}
\hline Study & $\begin{array}{l}\text { Period; } \\
\text { frequency }\end{array}$ & $\begin{array}{l}\text { Exchange } \\
\text { rates }\end{array}$ & Central banks & Analyses and results \\
\hline $\begin{array}{l}\text { Good- } \\
\text { hart and } \\
\text { Hesse } \\
\text { (1993) }\end{array}$ & $\begin{array}{l}10 . \text { Apr. } \\
89-29 . \\
\text { Jun. } 89 \\
\text { mainly } 30 \\
\text { min. }\end{array}$ & $\begin{array}{l}\text { DEM/USD } \\
\text { JPY/USD } \\
\text { USD/GBP }\end{array}$ & $\begin{array}{l}\text { All central } \\
\text { banks being } \\
\text { reported, i.e. } \\
\text { more than } 8\end{array}$ & $\begin{array}{l}\text { - no price impact } \\
\text { - intervention conditions, when thin } \\
\text { markets, high volatility, prior price } \\
\text { changes }\end{array}$ \\
\hline $\begin{array}{l}\text { Peiers } \\
(1997)\end{array}$ & $\begin{array}{l}\text { Oct. } 92- \\
\text { Sep. } 93 \text {; } \\
1 \text { min. }\end{array}$ & $\begin{array}{l}\text { DEM vs. } \\
\text { EMS cur- } \\
\text { rencies }\end{array}$ & $\begin{array}{l}\text { Deutsche } \\
\text { Bundesbank }\end{array}$ & $\begin{array}{l}\text { - event study } 60 \text { min. before and after } \\
\text { intervention announcement } \\
\text { - price leadership of Deutsche Bank } \\
\text { - traders know intervention about 30- } \\
60 \text { min. before news becomes pub- } \\
\text { lished }\end{array}$ \\
\hline $\begin{array}{l}\text { Chang } \\
\text { and } \\
\text { Taylor } \\
\text { (1998) }\end{array}$ & $\begin{array}{l}\text { Oct. } 92- \\
\text { Sep. 93; } \\
1 \text { min. }\end{array}$ & JPY/USD & $\begin{array}{l}\text { Federal Re- } \\
\text { serve }\end{array}$ & $\begin{array}{l}\text { - event study } 60 \text { min. before and after } \\
\text { interventions } \\
\text { - Volatility is higher during interven- } \\
\text { tion times } \\
\text { - Volatility increases } 30 \text { min. before } \\
\text { actual interventions } \\
\text { macro news as control variable }\end{array}$ \\
\hline $\begin{array}{l}\text { Domin- } \\
\text { guez } \\
(2003)\end{array}$ & $\begin{array}{l}87 \text { - Aug. } \\
95 ; \\
\text { tick-by- } \\
\text { tick, } \\
5 \text { min. }\end{array}$ & $\begin{array}{l}\text { DEM/USD } \\
\text { JPY/USD }\end{array}$ & $\begin{array}{l}\text { Federal Re- } \\
\text { serve (also } \\
\text { considers in- } \\
\text { tervention with } \\
\text { G3 central } \\
\text { banks) }\end{array}$ & $\begin{array}{l}\text { - event study: } 2 \text { hours before and after } \\
\text { interventions } \\
\text { - impact on returns } \\
\text { - impact higher, if higher trading vol- } \\
\text { ume, if directly after macro an- } \\
\text { nouncements, if coordinated } \\
\text { volatility higher around interventions }\end{array}$ \\
\hline $\begin{array}{l}\text { Domin- } \\
\text { guez } \\
(2006)\end{array}$ & $\begin{array}{l}\text { Aug. } 89- \\
\text { Aug. } 95 \text {; } \\
\text { tick-by- } \\
\text { tick } \\
5 \text { min. }\end{array}$ & $\begin{array}{l}\text { DEM/USD } \\
\text { JPY/USD }\end{array}$ & $\begin{array}{l}\text { Federal Re- } \\
\text { serve, } \\
\text { Deutsche } \\
\text { Bundesbank, } \\
\text { Bank of Japan }\end{array}$ & $\begin{array}{l}\text { - paper confirms Dominguez (2003) } \\
\text { on volatility findings } \\
\text { - the approach considers } \\
\text { intradaily seasonal market activity } \\
\text { pattern }\end{array}$ \\
\hline $\begin{array}{l}\text { Chari } \\
(2007)\end{array}$ & $\begin{array}{l}\text { Oct. } 92 \text { - } \\
\text { Sep. 93; } \\
\text { tick-by- } \\
\text { tick }\end{array}$ & JPY/USD & $\begin{array}{l}\text { Federal Re- } \\
\text { serve, Bank of } \\
\text { Japan }\end{array}$ & $\begin{array}{l}\text { - event study: } 2 \text { hours before and after } \\
\text { interventions } \\
\text { - volatility and spread are higher after } \\
\text { interventions } \\
\text { - top ten most active banks react very } \\
\text { differently with their quotes on in- } \\
\text { tervention }\end{array}$ \\
\hline $\begin{array}{l}\text { Cai et } \\
\text { al. } \\
(2001)\end{array}$ & $\begin{array}{l}\text { Jan. - Dec. } \\
98 \text {; } \\
5 \text { min. }\end{array}$ & JPY/USD & $\begin{array}{l}\text { Federal Re- } \\
\text { serve; Bank of } \\
\text { Japan }\end{array}$ & $\begin{array}{l}\text { - the approach consides intraday vola- } \\
\text { tility pattern } \\
\text { - volatility higher at intervention days }\end{array}$ \\
\hline
\end{tabular}




\section{Table 2. Studies on the accuracy of intervention press reports}

\begin{tabular}{|c|c|c|c|c|}
\hline Study & $\begin{array}{l}\text { Period; } \\
\text { source }\end{array}$ & $\begin{array}{l}\text { Exchange } \\
\text { rates }\end{array}$ & $\begin{array}{l}\text { Central } \\
\text { banks }\end{array}$ & Results \\
\hline $\begin{array}{l}\text { Klein } \\
\text { (1993) }\end{array}$ & $\begin{array}{l}\text { Jan. } 85- \\
\text { Dec. } 89 \\
\text { New York } \\
\text { Times, Wall } \\
\text { Street Jour- } \\
\text { nal }\end{array}$ & $\begin{array}{l}\text { DEM/USD } \\
\text { JPY/USD }\end{array}$ & $\begin{array}{l}\text { Federal } \\
\text { Reserve }\end{array}$ & $\begin{array}{l}\text { - } 72 \% \text { of actual interventions are } \\
\text { reported (daily data) } \\
\text { - } 88 \% \text { of reported interventions do } \\
\text { occur } \\
\text { - larger interventions are better } \\
\text { reported }\end{array}$ \\
\hline $\begin{array}{l}\text { Fischer } \\
\text { (2006) }\end{array}$ & $\begin{array}{l}\text { Jan. } 89- \\
\text { Aug. } 95 \\
\text { Reuters }\end{array}$ & $\begin{array}{l}\text { SFR/USD } \\
\text { DEM/USD } \\
\text { JPY/USD } \\
\text { SFR/DEM }\end{array}$ & $\begin{array}{l}\text { Swiss } \\
\text { National } \\
\text { Bank }\end{array}$ & $\begin{array}{l}\text { - about } 90 \% \text { of actual interventions } \\
\text { (per day) are reported } \\
\text { - } 100 \% \text { of reported interventions do } \\
\text { occur } \\
\text { - the reported timing of interventions is } \\
\text { often imprecise by hours } \\
\text { - reporting precision increases over } \\
\text { time }\end{array}$ \\
\hline $\begin{array}{l}\text { Frenkel et } \\
\text { al. (2004) }\end{array}$ & $\begin{array}{l}\text { Jan. 95 - } \\
\text { Dec. 99; } \\
\text { Financial } \\
\text { Times, Wall } \\
\text { Street Jour- } \\
\text { nal }\end{array}$ & JPY/USD & $\begin{array}{l}\text { Bank of } \\
\text { Japan }\end{array}$ & $\begin{array}{l}\text { - } 45 \% \text { of actual interventions are re- } \\
\text { ported (daily data) } \\
\text { - } 60 \% \text { of repeated interventions do } \\
\text { occur } \\
\text { - larger interventions are not better } \\
\text { reported, but coordinated interven- } \\
\text { tions are }\end{array}$ \\
\hline $\begin{array}{l}\text { Galati et al. } \\
\text { (2001) }\end{array}$ & $\begin{array}{l}\text { Sep. } 93- \\
\text { Apr. 00; } \\
\text { Reuters }\end{array}$ & JPY/USD & $\begin{array}{l}\text { Bank of } \\
\text { Japan }\end{array}$ & $\begin{array}{l}\text { - } 77 \% \text { of actual interventions are re- } \\
\text { ported (daily data) } \\
\text { - } 84 \% \text { of reported interventions do } \\
\text { occur }\end{array}$ \\
\hline
\end{tabular}


Table 3. Intervention studies based on transaction data

\begin{tabular}{|c|c|c|c|c|}
\hline Study & $\begin{array}{l}\text { Period; } \\
\text { frequency }\end{array}$ & $\begin{array}{l}\text { Exchange } \\
\text { rates }\end{array}$ & $\begin{array}{l}\text { Central } \\
\text { banks }\end{array}$ & Analyses and results \\
\hline $\begin{array}{l}\text { Fischer } \\
\text { and Zur- } \\
\text { linden } \\
\text { (1998) }\end{array}$ & $\begin{array}{l}\text { Jan. } 86 \text { - Dec. } \\
94 ; \quad \text { irregu- } \\
\text { lar }\end{array}$ & SFR/USD & $\begin{array}{l}\text { Swiss } \\
\text { National } \\
\text { Bank }\end{array}$ & $\begin{array}{l}\text { - interventions have price impact, but } \\
\text { other central bank transactions have } \\
\text { not } \\
\text { - first intervention of a sequence has } \\
\text { impact }\end{array}$ \\
\hline $\begin{array}{l}\text { Payne and } \\
\text { Vitale } \\
(2003)\end{array}$ & $\begin{array}{l}\text { Jan. } 86 \text { - Dec. } \\
95 ; \\
15 \text { min. }\end{array}$ & SFR/USD & $\begin{array}{l}\text { Swiss } \\
\text { National } \\
\text { Bank }\end{array}$ & $\begin{array}{l}\text { - apply Hasbrouck (1991) price } \\
\text { impact SVAR approach } \\
\text { - impact is higher, if interventions } \\
\text { go with the market and if they are } \\
\text { concerted } \\
\text { - some interventions seem to be } \\
\text { anticipated }\end{array}$ \\
\hline $\begin{array}{l}\text { Pasquar- } \\
\text { iello } \\
(2007)\end{array}$ & $\begin{array}{l}\text { Jan. } 86 \text { - Dec. } \\
98 ; \\
5 \text { min. }\end{array}$ & SFR/USD & $\begin{array}{l}\text { Swiss } \\
\text { National } \\
\text { Bank }\end{array}$ & $\begin{array}{l}\text { - interventions are related to } \\
\text { increased volatility and spread }\end{array}$ \\
\hline $\begin{array}{l}\text { Beattie } \\
\text { and Fil- } \\
\text { lion } \\
\text { (1999) }\end{array}$ & $\begin{array}{l}\text { Apr. } 95 \text { - Sep. } \\
97 ; \\
10 \text { min. }\end{array}$ & CAD/USD & $\begin{array}{l}\text { Bank of } \\
\text { Canada }\end{array}$ & $\begin{array}{l}\text { - time series approach, control for } \\
\text { intraday seasonal pattern, for daily } \\
\text { volatility persistence and macro } \\
\text { news } \\
\text { - unexpected interventions reduce } \\
\text { volatility } \\
\text { - the non-intervention band tends } \\
\text { to stabilize exchange rates }\end{array}$ \\
\hline $\begin{array}{l}\text { Fatum } \\
\text { and King } \\
(2005)\end{array}$ & $\begin{array}{l}\text { Jan. } 95 \text { - Sep. } \\
98 ; \\
5 \text { min. }\end{array}$ & CAD/USD & $\begin{array}{l}\text { Bank of } \\
\text { Canada }\end{array}$ & $\begin{array}{l}\text { - event study approach } \\
\text { - price impact on returns } \\
\text { - interventions reduce volatility, } \\
\text { but effect disappears when consid- } \\
\text { ering currency co-movement } \\
\text { - the same impact of discretionary } \\
\text { and mechanistic (rules based) inter- } \\
\text { ventions }\end{array}$ \\
\hline $\begin{array}{l}\text { Kim } \\
(2007)\end{array}$ & $\begin{array}{l}\text { May } 91 \text { - Mar. } \\
\text { 04; } \\
3 \text { intervals }\end{array}$ & JPY/USD & $\begin{array}{l}\text { Bank of } \\
\text { Japan }\end{array}$ & $\begin{array}{l}\text { - } \text { regime-dependent impact on } \\
\text { returns } \\
\text { - interventions reduce volatility } \\
\text { significantly overnight (but not con- } \\
\text { temporaneously) }\end{array}$ \\
\hline $\begin{array}{l}\text { Fatum } \\
\text { and } \\
\text { Pedersen } \\
\text { (2007) }\end{array}$ & $\begin{array}{l}\text { Jan. } 02 \text { - Dec. } \\
04 \text {; } \\
5 \text { min. }\end{array}$ & DKK/EUR & $\begin{array}{l}\text { Denmarks } \\
\text { National- } \\
\text { bank }\end{array}$ & $\begin{array}{l}\text { - interventions have price impact } \\
\text { - effect is higher if consistent with } \\
\text { fundamentals and if volatility is } \\
\text { high } \\
\text { - adjustment to intervention news } \\
\text { may need about } 30 \text { min. }\end{array}$ \\
\hline
\end{tabular}




\section{Table 4. Intervention studies based on order flow data}

\begin{tabular}{|c|c|c|c|c|}
\hline Study & $\begin{array}{l}\text { Period; } \\
\text { frequency }\end{array}$ & $\begin{array}{l}\text { Exchange } \\
\text { rates }\end{array}$ & $\begin{array}{l}\text { Central } \\
\text { banks }\end{array}$ & analyses and results \\
\hline $\begin{array}{l}\text { Evans } \\
\text { and Ly- } \\
\text { ons } \\
(2005)\end{array}$ & $\begin{array}{l}\text { May - Aug. 96; } \\
\text { hourly }\end{array}$ & DEM/USD & - & $\begin{array}{l}\text { - analyze the regular price impact: } \\
0.44 \text { basis points per } 10 \text { mill USD } \\
\text { - this indicates the impact of secret } \\
\text { interventions }\end{array}$ \\
\hline $\begin{array}{l}\text { Scalia } \\
\text { (2008) }\end{array}$ & $\begin{array}{l}\text { Jul. - Dec.02; } \\
\text { transactions - } \\
\text { hourly }\end{array}$ & CZK/EUR & $\begin{array}{l}\text { Czech } \\
\text { National } \\
\text { Bank }\end{array}$ & $\begin{array}{l}\text { - } \text { regular price impact: } 6.6 \text { basis } \\
\text { points } \\
\text { - secret interventions but still high } \\
\text { likelihood: } 9.3 \text { basis points } \\
\text { - interventions with high likelihood } \\
\text { and learning: } 12.2 \text { basis points }\end{array}$ \\
\hline $\begin{array}{l}\text { Giradin } \\
\text { and Ly- } \\
\text { ons } \\
(2007)\end{array}$ & $\begin{array}{l}\text { July } 95- \\
\text { March 04; } \\
\text { daily }\end{array}$ & YEN/USD & $\begin{array}{l}\text { Bank of } \\
\text { Japan, } \\
\text { Federal } \\
\text { Reserve }\end{array}$ & $\begin{array}{l}\text { - intervention impacts return (even } \\
\text { controlled for other order flow) } \\
\text { - no robust impact on volatility } \\
\text { - no clear evidence on a damping } \\
\text { and coordination channel }\end{array}$ \\
\hline $\begin{array}{l}\text { Melvin et } \\
\text { al. (2008) }\end{array}$ & $\begin{array}{l}\text { March } 02(1- \\
22) \text {, all orders, } \\
30 \text { seconds }\end{array}$ & RUR/USD & $\begin{array}{l}\text { Bank of } \\
\text { Russia }\end{array}$ & $\begin{array}{l}\text { - intervention increases volatility } \\
\text { and spread for minutes } \\
\text { - intervention days have lower vola- } \\
\text { tility and spread than non- } \\
\text { intervention days } \\
\text { - informed banks take positions } \\
\text { against the intervention band } \\
\text { - interventions increase trading } \\
\text { volume and decrease spread }\end{array}$ \\
\hline
\end{tabular}




\section{CESifo Working Paper Series}

for full list see www.cesifo-group.org/wp

(address: Poschingerstr. 5, 81679 Munich, Germany, office@cesifo.de)

2413 Thorsten Upmann, Labour Unions - To Unite or to Separate?, October 2008

2414 Sascha O. Becker and Ludger Woessmann, Luther and the Girls: Religious Denomination and the Female Education Gap in $19^{\text {th }}$ Century Prussia, October 2008

2415 Florian Englmaier and Stephen Leider, Contractual and Organizational Structure with Reciprocal Agents, October 2008

2416 Vittorio Daniele and Ugo Marani, Organized Crime and Foreign Direct Investment: The Italian Case, October 2008

2417 Valentina Bosetti, Carlo Carraro, Alessandra Sgobbi and Massimo Tavoni, Modelling Economic Impacts of Alternative International Climate Policy Architectures. A Quantitative and Comparative Assessment of Architectures for Agreement, October 2008

2418 Paul De Grauwe, Animal Spirits and Monetary Policy, October 2008

2419 Guglielmo Maria Caporale, Christophe Rault, Robert Sova and Anamaria Sova, On the Bilateral Trade Effects of Free Trade Agreements between the EU-15 and the CEEC-4 Countries, October 2008

2420 Yin-Wong Cheung and Daniel Friedman, Speculative Attacks: A Laboratory Study in Continuous Time, October 2008

2421 Kamila Fialová and Ondřej Schneider, Labour Market Institutions and their Effect on Labour Market Performance in the New EU Member Countries, October 2008

2422 Alexander Ludwig and Michael Reiter, Sharing Demographic Risk - Who is Afraid of the Baby Bust?, October 2008

2423 Doina Maria Radulescu and Michael Stimmelmayr, The Welfare Loss from Differential Taxation of Sectors in Germany, October 2008

2424 Nikolaus Wolf, Was Germany ever United? Evidence from Intra- and International Trade 1885 - 1933, October 2008

2425 Bruno S. Frey, David A. Savage and Benno Torgler, Noblesse Oblige? Determinants of Survival in a Life and Death Situation, October 2008

2426 Giovanni Facchini, Peri Silva and Gerald Willmann, The Customs Union Issue: Why do we Observe so few of them?, October 2008 
2427 Wido Geis, Silke Uebelmesser and Martin Werding, Why go to France or Germany, if you could as well go to the UK or the US? Selective Features of Immigration to four major OECD Countries, October 2008

2428 Geeta Kingdon and Francis Teal, Teacher Unions, Teacher Pay and Student Performance in India: A Pupil Fixed Effects Approach, October 2008

2429 Andreas Haufler and Marco Runkel, Firms' Financial Choices and Thin Capitalization Rules under Corporate Tax Competition, October 2008

2430 Matz Dahlberg, Heléne Lundqvist and Eva Mörk, Intergovernmental Grants and Bureaucratic Power, October 2008

2431 Alfons J. Weichenrieder and Tina Klautke, Taxes and the Efficiency Costs of Capital Distortions, October 2008

2432 Andreas Knabe and Ronnie Schöb, Minimum Wage Incidence: The Case for Germany, October 2008

2433 Kurt R. Brekke and Odd Rune Straume, Pharmaceutical Patents: Incentives for R\&D or Marketing?, October 2008

2434 Scott Alan Carson, Geography, Insolation, and Institutional Change in $19^{\text {th }}$ Century African-American and White Stature in Southern States, October 2008

2435 Emilia Del Bono and Daniela Vuri, Job Mobility and the Gender Wage Gap in Italy, October 2008

2436 Marco Angrisani, Antonio Guarino, Steffen Huck and Nathan Larson, No-Trade in the Laboratory, October 2008

2437 Josse Delfgaauw and Robert Dur, Managerial Talent, Motivation, and Self-Selection into Public Management, October 2008

2438 Christian Bauer and Wolfgang Buchholz, How Changing Prudence and Risk Aversion Affect Optimal Saving, October 2008

2439 Erich Battistin, Clara Graziano and Bruno Parigi, Connections and Performance in Bankers' Turnover: Better Wed over the Mixen than over the Moor, October 2008

2440 Erkki Koskela and Panu Poutvaara, Flexible Outsourcing and the Impacts of Labour Taxation in European Welfare States, October 2008

2441 Marcelo Resende, Concentration and Market Size: Lower Bound Estimates for the Brazilian Industry, October 2008

2442 Giandomenico Piluso and Roberto Ricciuti, Fiscal Policy and the Banking System in Italy. Have Taxes, Public Spending and Banks been Procyclical in the Long-Run? October 2008 
2443 Bruno S. Frey and Katja Rost, Do Rankings Reflect Research Quality?, October 2008

2444 Guglielmo Maria Caporale, Antoaneta Serguieva and Hao Wu, Financial Contagion: Evolutionary Optimisation of a Multinational Agent-Based Model, October 2008

2445 Valentina Bosetti, Carlo Carraro and Massimo Tavoni, Delayed Participation of Developing Countries to Climate Agreements: Should Action in the EU and US be Postponed?, October 2008

2446 Alexander Kovalenkov and Xavier Vives, Competitive Rational Expectations Equilibria without Apology, November 2008

2447 Thiess Buettner and Fédéric Holm-Hadulla, Cities in Fiscal Equalization, November 2008

2448 Harry H. Kelejian and Ingmar R. Prucha, Specification and Estimation of Spatial Autoregressive Models with Autoregressive and Heteroskedastic Disturbances, November 2008

2449 Jan Bouckaert, Hans Degryse and Thomas Provoost, Enhancing Market Power by Reducing Switching Costs, November 2008

2450 Frank Heinemann, Escaping from a Combination of Liquidity Trap and Credit Crunch, November 2008

2451 Dan Anderberg, Optimal Policy and the Risk Properties of Human Capital Reconsidered, November 2008

2452 Christian Keuschnigg and Evelyn Ribi, Outsourcing, Unemployment and Welfare Policy, November 2008

2453 Bernd Theilen, Market Competition and Lower Tier Incentives, November 2008

2454 Ondřej Schneider, Voting in the European Union - Central Europe's Lost Voice, November 2008

2455 Oliver Lorz and Gerald Willmann, Enlargement versus Deepening: The Trade-off Facing Economic Unions, November 2008

2456 Alfons J. Weichenrieder and Helen Windischbauer, Thin-Capitalization Rules and Company Responses, Experience from German Legislation, November 2008

2457 Andreas Knabe and Steffen Rätzel, Scarring or Scaring? The Psychological Impact of Past Unemployment and Future Unemployment Risk, November 2008

2458 John Whalley and Sean Walsh, Bringing the Copenhagen Global Climate Change Negotiations to Conclusion, November 2008

2459 Daniel Mejía, The War on Illegal Drugs in Producer and Consumer Countries: A Simple Analytical Framework, November 2008 
2460 Carola Frydman, Learning from the Past: Trends in Executive Compensation over the Twentieth Century, November 2008

2461 Wolfgang Ochel, The Political Economy of Two-tier Reforms of Employment Protection in Europe, November 2008

2462 Peter Egger and Doina Maria Radulescu, The Influence of Labor Taxes on the Migration of Skilled Workers, November 2008

2463 Oliver Falck, Stephan Heblich and Stefan Kipar, The Extension of Clusters: Differencein-Differences Evidence from the Bavarian State-Wide Cluster Policy, November 2008

2464 Lei Yang and Keith E. Maskus, Intellectual Property Rights, Technology Transfer and Exports in Developing Countries, November 2008

2465 Claudia M. Buch, The Great Risk Shift? Income Volatility in an International Perspective, November 2008

2466 Walter H. Fisher and Ben J. Heijdra, Growth and the Ageing Joneses, November 2008

2467 Louis Eeckhoudt, Harris Schlesinger and Ilia Tsetlin, Apportioning of Risks via Stochastic Dominance, November 2008

2468 Elin Halvorsen and Thor O. Thoresen, Parents' Desire to Make Equal Inter Vivos Transfers, November 2008

2469 Anna Montén and Marcel Thum, Ageing Municipalities, Gerontocracy and Fiscal Competition, November 2008

2470 Volker Meier and Matthias Wrede, Reducing the Excess Burden of Subsidizing the Stork: Joint Taxation, Individual Taxation, and Family Splitting, November 2008

2471 Gunther Schnabl and Christina Ziegler, Exchange Rate Regime and Wage Determination in Central and Eastern Europe, November 2008

2472 Kjell Erik Lommerud and Odd Rune Straume, Employment Protection versus Flexicurity: On Technology Adoption in Unionised Firms, November 2008

2473 Lukas Menkhoff, High-Frequency Analysis of Foreign Exchange Interventions: What do we learn?, November 2008 